\title{
Political uncertainty and corporate investment: Empirical evidence from China
}

\author{
Miaochen Lv*, ${ }^{1}$, Manying Bai ${ }^{1}$ \\ ${ }^{1}$ School of Economics and Management Beihang University Beijing, China
}

\begin{abstract}
Using data of Chinese listed companies and local officials' turnover, this paper examines the impact of political uncertainty on corporate investment in China. Results show that during the change of officials, companies will significantly reduce investment, despite the different measures of political uncertainty. This situation is more obvious for external appointment, state-owned enterprises and capitalintensive firms. Moreover, this paper creatively finds that this influence of provincial political uncertainty is more pronounced than that of municipal political uncertainty. Besides, the volatility of corporate investment increase with political uncertainty.
\end{abstract}

\section{INTRODUCTION}

The orderly operation and long-term development of an enterprise depends not only on the stability of internal operations, but also on the external political environment. The political uncertainty caused by the officials' turnover has a significant impact on business operations, especially in China. Different from Western countries, China's fiscal decentralization political system and officials' promotion as well as evaluation mechanism promote officials to influence the decision-making behavior of enterprises through political intervention or policy changes [1], which leads to the local government in China to play an increasingly important role in local economic development [2]. Therefore, the Chinese situation is particularly suitable for studying the impact of political uncertainty on corporate business decisions.

Investment activities are not only very important to business operations, but also the main way for the government to intervene in economic activities in order to achieve political performance goals. However, the turnover of government officials produces additional risk which may result in a bad outcome. Frequent replacement of officials will weaken the sustainability of local government policies, undermine the stability of business environment, and affect corporate behavior. Considering this, corporate normally postpone or reduce investment until the political uncertainty is resolved [3, 4]. Julio and Yook (2012) found that during election year, firm investment and cross-border capital flow reduce by $4.8 \%$ [5]. After controlling investment opportunities, Yonce (2015) found that during the US presidential elections from 1964 to 2008, US companies reduced their investment expenditures by an average of about $2.0 \%$, reduced by an average of $5.3 \%$ during the one-party administration, and reduced by $8.7 \%$ during the
Republican administration [6]. Although there has been a lot of research focus on the impact of political uncertainty on corporate investment decisions, most of the literature studied multiple countries, the research on single country, especially China is relatively limited, and the research is not comprehensive and in-depth. Therefore, this paper uses a variety of methods to measure political uncertainty, as well as studies the difference between provincial and municipal government officials change, etc., to make up for the existing lack of documentation.

\section{DATA AND SAMPLE}

\subsection{Political uncertainty}

This paper takes 334 prefecture-level cities in 31 provinces of mainland China as the sample, and measures political uncertainty based on the information of political officials' turnover at the provincial and prefecture levels from 1991 to 2017. Data are collected from CSMAR database.

Specifically, taking prefecture-level cities as an example, this paper uses PU to measure the political uncertainty caused by the turnover of prefecture-level officials. If the government officials change before June 30 of year $t$, year $t$ is defined as political uncertainty year, assigned a value of 1 . If the government official has not changed in year $t$, then assign a value of 0 . In addition, in order to distinguish the difference of political uncertainty caused by the changes of the mayor and the municipal party secretary, this paper uses $\mathrm{pu}$ sz and pu_sj to represent different uncertainty type, respectively. Similarly, the political uncertainty at provincial level is defined as pu_psz and pu_psj.

The different reasons of officials' turnover lead to different level of political uncertainty. Taking the change

\footnotetext{
* Corresponding author: lvmiaochen0130@buaa.edu.cn
} 
of mayor as an example, the situation without the mayor change is defined as reason_sz $=0$, and the normal resignation at the end of the term, including the normal transfer caused by promotion and other reasons, is defined as reason_sz $=1$. The situation of abnormal resignation due to the death and other reasons is defined as reason $s z=2$, and the situation of abnormal resignation caused by corruption and other illegal criminal acts during employment is defined as reason_sz $=3$.

Moreover, this paper uses different promotion methods of newly appointed local officials to further measure the level of political uncertainty. Specifically, if the last position of a local government official came from another prefecture-level city, this paper considers the official to be an external appointment type. That is, this paper defines external $=1$, otherwise 0 .

\subsection{Corporate investment and control variables}

Following previous research [7], corporate investment is defined as the net fixed assets in year t-net fixed assets in year $t-1$ plus asset depreciation in year $t$, then scaled by total assets in year t. Meanwhile, the control variables selected in this paper include size(company size, calculated by the natural logarithm of market value), level (total asset-liability ratio, equal to the total liabilities scaled by total assets), tobinq (equal to the total market value scaled by total assets), cash (cash holdings, equal to free cash flow scaled by total assets), roa (return on asset, calculated as the net profit divided by total assets), H10 (Herfindahl index, representing the equity concentration), age (firm age), $\mathrm{SOE}$ (a dummy variable of corporate ownership, which equals to 1 for SOEs, and zero for nonSOEs), Year (a dummy variable of years) and Industry (a dummy variable of industry factors).

\section{EMPIRICAL RESULTS}

The impact of political uncertainty on corporate investment is examined based on the following model:

investment $_{i, t}=\beta_{0}+\beta_{1} P U_{i, t}+\beta_{2}$ investment $_{i, t-1}+\beta_{3}$ size $_{i, t-1}$

$+\beta_{4}$ level $_{i, t-1}+\beta_{5}$ tobinq $_{i, t-1}+\beta_{6}$ cash $_{i, t-1}+\beta_{7}$ roa $_{i, t-1}$

$+\beta_{8} H_{10}{ }_{i, t-1}+\beta_{9}$ age $_{i, t-1}+\sum \beta_{i}$ Year $_{i, t}+\sum \beta_{i}$ Industry $_{i, t}+\varepsilon_{i, t}$

In addition, five different variables, including mayor turnover (pu_sz), secretary turnover (pu_sj) and official turnover reason (reason_sz, reason_sj and reason), are considered as the alternative variables of political uncertainty (PU) for robustness. The regression results of Eq. (1) reported in Table 1 show that the estimated coefficients of political uncertainty with six different measurements are all significantly negative at $1 \%$ level. Then, this paper draws a relatively robust conclusion that political uncertainty is negatively related to corporate investment. Meanwhile, the significant estimated coefficients of control variables are reported to be consistent with existing literature. Specifically, corporate investment is positively associated with cash holding, return on asset, equity concentration and firm age, but negatively associated with corporate investment in previous period, firm size, the asset-liability ratio and TobinQ.

TABLE I. POLITICAL UNCERTAINTY AND CORPORATE INVESTMENT

\begin{tabular}{|c|c|c|c|c|c|c|}
\hline investment & pu_sz & reason_sz & pu_sj & reason_sj & $\mathrm{pu}$ & reason \\
\hline \multirow{2}{*}{ PU } & $-0.016^{* * *}$ & $-0.153 * * *$ & $-0.015 * * *$ & $-0.101 * * *$ & $-0.011 * * *$ & $-0.092 * * *$ \\
\hline & $(-7.792)$ & $(-7.785)$ & $(-7.519)$ & $(-6.408)$ & $(-9.511)$ & $(-8.767)$ \\
\hline \multirow{2}{*}{$\begin{array}{c}\mathrm{L} 1 \\
\text {.investment }\end{array}$} & $-0.203^{* * *}$ & $-0.203^{* * *}$ & $-0.201^{* * *}$ & $-0.201 * * *$ & $-0.202^{* * *}$ & $-0.202 * * *$ \\
\hline & $(-20.073)$ & $(-20.073)$ & $(-19.973)$ & $(-19.953)$ & $(-20.091)$ & $(-20.065)$ \\
\hline \multirow{2}{*}{ size } & $-0.011 * * *$ & $-0.011 * * *$ & $-0.011 * * *$ & $-0.011 * * *$ & $-0.011 * * *$ & $-0.011 * * *$ \\
\hline & $(-11.502)$ & $(-11.525)$ & $(-11.591)$ & $(-11.705)$ & $(-11.463)$ & $(-11.584)$ \\
\hline \multirow{2}{*}{ level } & $-0.022 * * *$ & $-0.022 * * *$ & $-0.021 * * *$ & $-0.021 * * *$ & $-0.022 * * *$ & $-0.021 * * *$ \\
\hline & $(-3.371)$ & $(-3.363)$ & $(-3.265)$ & $(-3.151)$ & $(-3.403)$ & $(-3.289)$ \\
\hline \multirow{2}{*}{ tobinq } & $-0.016^{* * *}$ & $-0.016^{* * *}$ & $-0.016 * * *$ & $-0.016^{* * *}$ & $-0.016 * * *$ & $-0.016^{* * *}$ \\
\hline & $(-24.922)$ & $(-24.927)$ & $(-24.907)$ & $(-24.927)$ & $(-24.935)$ & $(-24.957)$ \\
\hline \multirow{2}{*}{ cash } & $0.003 * * *$ & $0.003 * * *$ & $0.004 * * *$ & $0.004 * * *$ & $0.004 * * *$ & $0.004 * * *$ \\
\hline & $(5.976)$ & $(5.978)$ & (6.093) & (6.154) & (6.033) & (6.109) \\
\hline \multirow{2}{*}{ roa } & $0.059 * * *$ & $0.059 * * *$ & $0.059 * * *$ & $0.060^{* * *}$ & $0.059 * * *$ & $0.060 * * *$ \\
\hline & $(2.782)$ & $(2.796)$ & $(2.763)$ & (2.809) & $(2.767)$ & $(2.815)$ \\
\hline \multirow{2}{*}{ H10 } & $0.045^{* * *}$ & $0.045^{* * *}$ & $0.046^{* * *}$ & $0.046 * * *$ & $0.045 * * *$ & $0.045 * * *$ \\
\hline & (5.536) & (5.539) & (5.632) & (5.648) & $(5.545)$ & $(5.571)$ \\
\hline \multirow{2}{*}{ age } & $0.000 *$ & $0.000^{*}$ & $0.000 * *$ & $0.000^{* *}$ & $0.000^{* *}$ & $0.000 * *$ \\
\hline & (1.910) & (1.904) & (2.032) & (1.981) & (2.028) & (2.003) \\
\hline \multirow{2}{*}{ Constant } & $0.293 * * *$ & $0.293 * * *$ & $0.293^{* * *}$ & $0.294 * * *$ & $0.293 * * *$ & $0.294 * * *$ \\
\hline & (14.092) & (14.111) & (14.132) & (14.162) & (14.148) & (14.196) \\
\hline Year & Yes & Yes & Yes & Yes & Yes & Yes \\
\hline Industry & Yes & Yes & Yes & Yes & Yes & Yes \\
\hline Observations & 14,157 & 14,157 & 14,157 & 14,157 & 14,157 & 14,157 \\
\hline $\mathrm{R}^{\wedge} 2$ & 0.144 & 0.144 & 0.144 & 0.143 & 0.146 & 0.145 \\
\hline
\end{tabular}


Note: ${ }^{*} * *$ and $* * *$ indicate statistical significance at the $10 \%, 5 \%$ and $1 \%$ levels, respectively.

In addition, the estimated coefficients of the variable external are all significantly negative in Table 2 , which suggest that the impact of political uncertainty caused by external appointments on corporate investment is greater than the political uncertainty caused by local promotion. A possible explanation is that external appointments lead to a higher degree of political uncertainty due to the more opaque and unpredictable political preferences of external appointees.

TABLE II. OFFICIAL PROMOTION TYPE AND CORPORATE INVESTMENT

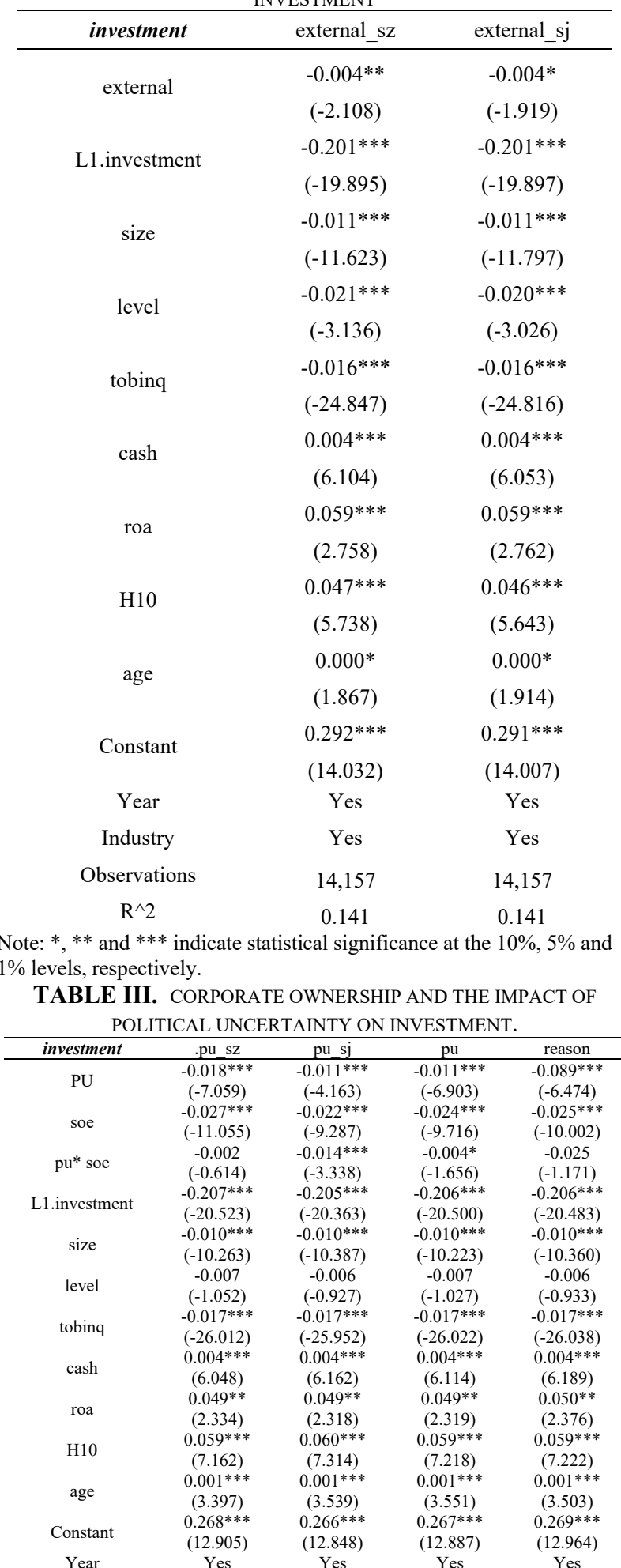

\begin{tabular}{ccccc}
\hline Industry & Yes & Yes & Yes & Yes \\
Observations & 14,157 & 14,157 & 14,157 & 14,157 \\
$\mathrm{R}^{\wedge} 2$ & 0.154 & 0.155 & 0.156 & 0.155 \\
\hline Note $* * *$ and $* * *$ indicate statistical significance at the $10 \%, 5 \%$ and
\end{tabular}

Note: $* * *$ and $* * *$ indicate statistical significance at the $10 \%, 5 \%$ and $1 \%$ levels, respectively.

The negative impact of political uncertainty on corporate investment may also vary among different type of corporates. Thus, this paper expands the research from the following two aspects:

Firstly, this paper examines the effect of corporate ownership. The results in Table 3 show that the estimated coefficients of four political uncertainty are all significantly negative, which confirms the previous conclusion. The estimated coefficients of soe and the interaction term $p u$ *soe are all negative, which suggests that there is a greater decrease in corporate investment of state-owned enterprises (SOEs) than corporate investment of non-SOEs during official turnover period.

Secondly, this paper examines the effect of corporate capital intensity. Corporate capital intensity is calculated as corporate fixed assets scaled by total assets. The dummy variable cap is equal to 1 if the firm belongs to the top $50 \%$ capital intensity group, otherwise 0 . The estimated coefficients of the interaction term $p u^{*}$ cap is significantly negative, which suggest that companies with high capital intensity are more affected by political uncertainty, possible for the reason of frequent investment activities and the need for government approval on corporate investment.

TABLE IV. CORPORATE CAPITAL INTENSITY AND CORPORATE

\begin{tabular}{|c|c|}
\hline \multicolumn{2}{|c|}{ INVESTMENT } \\
\hline investment & .pu_sz \\
\hline PU & $\begin{array}{c}-0.006 * * * \\
(-5.748)\end{array}$ \\
\hline cap & $\begin{array}{c}0.025^{* * *} \\
(10.471)\end{array}$ \\
\hline pu* cap & $\begin{array}{c}-0.012 * * * \\
(-4.739)\end{array}$ \\
\hline L1.investment & $\begin{array}{c}-0.210^{* * *} \\
(-21.143)\end{array}$ \\
\hline size & $\begin{array}{c}-0.011^{* * *} \\
(-11.537)\end{array}$ \\
\hline level & $\begin{array}{c}-0.021 * * * \\
(-3.236)\end{array}$ \\
\hline tobinq & $\begin{array}{c}-0.015 * * * \\
(-23.806)\end{array}$ \\
\hline cash & $\begin{array}{c}0.004 * * * \\
(7.309)\end{array}$ \\
\hline roa & $\begin{array}{c}0.078^{* * *} \\
(3.648)\end{array}$ \\
\hline H10 & $\begin{array}{c}0.041^{* * *} \\
(5.068)\end{array}$ \\
\hline age & $\begin{array}{l}0.000 * * \\
(2.130)\end{array}$ \\
\hline Constant & $\begin{array}{c}0.281 * * * \\
(13.630)\end{array}$ \\
\hline Year & Yes \\
\hline Industry & Yes \\
\hline Observations & 14,157 \\
\hline $\mathrm{R}^{\wedge} 2$ & 0.153 \\
\hline
\end{tabular}


Note: *,** and $* * *$ indicate statistical significance at the $10 \%, 5 \%$ and $1 \%$ levels, respectively

The paper also examines the impact of political uncertainty caused by provincial officials' turnover on corporate investment. The estimated coefficients of pu_psz and pu_psj are all significantly negative in Table 5. Meanwhile, the absolute value of estimated coefficients, 0.033 and -0.031 , is even larger than that of prefecturelevel, which suggests that the negative impact of political uncertainty caused by provincial officials' turnover on corporate investment is significantly greater than political uncertainty at the municipal level.

Furtherly, this paper also explores the effect of political turnover frequency on volatility of corporate investment based on the following models:

$$
\begin{aligned}
& \text { inv_ } v_{i}=\beta_{0}+\beta_{1} P U_{-} \text {freq }+\beta_{2} \text { size } \_v_{i}+\beta_{3} \text { level } v_{i} \\
& +\beta_{4} \text { tobinq } v_{i}+\beta_{5} \text { cash_ } v_{i}+\beta_{6} \text { roa_ } v_{i}+\beta_{7} H_{1}{ }_{-} v_{i} \\
& +\beta_{8} \text { age_v } v_{i}+\sum \beta_{i} \text { Industry }{ }_{i}+\varepsilon_{i}
\end{aligned}
$$

Table 6 reports the results of Eq. (2). The estimated coefficient of PU_freq is significantly positive, which suggests that the volatility of corporate investment increase with more frequent government officials' turnover, indicating that corporate operation activities are more influenced due to greater uncertainty.

For robustness, this paper uses two-stage least squares (2SLS) method to verify the previous conclusion. The first-stage regression results show that the three instrument variables, including official age, education level and tenure, are all significantly relative to political uncertainty. And the second-stage regression results confirm the negative impact of political uncertainty to corporate investment. This paper also examines the subsample excluding the year of national leader turnover and removing the four municipalities, respectively. And the results are robust after removing the national-election-year effect and the national-election-year effect.

\begin{tabular}{|c|c|c|}
\hline investment & pu psz & $\mathrm{pu}$ psj \\
\hline \multirow[b]{2}{*}{$\mathrm{PU}$} & $-0.033 * * *$ & $-0.031 * * *$ \\
\hline & $(-16.243)$ & $(-13.027)$ \\
\hline \multirow{2}{*}{ L1.investment } & $-0.203 * * *$ & $-0.188 * * *$ \\
\hline & $(-20.437)$ & $(-18.892)$ \\
\hline \multirow{2}{*}{ size } & $-0.011 * * *$ & $-0.011 * * *$ \\
\hline & $(-11.298)$ & $(-12.112)$ \\
\hline \multirow{2}{*}{ level } & $-0.022 * * *$ & $-0.018 * * *$ \\
\hline & $(-3.427)$ & $(-2.791)$ \\
\hline \multirow{2}{*}{ tobinq } & $-0.016 * * *$ & $-0.016 * * *$ \\
\hline & $(-25.134)$ & $(-25.398)$ \\
\hline \multirow{2}{*}{ cash } & $0.004 * * *$ & $0.004 * * *$ \\
\hline & $(6.233)$ & $(6.592)$ \\
\hline \multirow{2}{*}{ roa } & $0.057 * * *$ & $0.057 * * *$ \\
\hline & $(2.705)$ & $(2.720)$ \\
\hline \multirow{2}{*}{ H10 } & $0.043 * * *$ & $0.046 * * *$ \\
\hline & $(5.268)$ & $(5.679)$ \\
\hline \multirow{2}{*}{ age } & $0.000 *$ & 0.000 \\
\hline & (1.800) & (1.473) \\
\hline \multirow{2}{*}{ Constant } & $0.295 * * *$ & $0.305^{* * *}$ \\
\hline & (14.283) & $(14.758)$ \\
\hline Year & Yes & Yes \\
\hline Industry & Yes & Yes \\
\hline Observations & 14,157 & 14,157 \\
\hline $\mathrm{R}^{\wedge} 2$ & 0.157 & 0.153 \\
\hline
\end{tabular}

TABLE V. PROVINCIAL POLITICAL UNCERTAINTY AND CORPORATE INVESTMENT

\section{CONCLUSION}

This paper studies the impact of political uncertainty on the investment of Chinese listed companies. This paper extends the measurements of political uncertainty based on the turnover reason, external appointment or local promotion and the political uncertainty at provincial level. All the empirical analyses confirm that political uncertainty has a significantly negative impact on corporate investment, and the effect is more obvious for external appointment, provincial turnover, state-owned enterprises and capital-intensive firms. Meanwhile, the investment volatility increases with the frequency of turnover. And the results are robust with various methods. This paper provides reference for companies' decisionmaking in the face of political uncertainty.

TABLE VI. GOVERNMENT OFFICIAL TURNOVER FREQUENCY AND CORPORATE INVESTMENT VOLATILITY

\begin{tabular}{cc}
\hline Variable & inv_v \\
\hline PU_freq & $8.950^{* *}$ \\
& $(2.458)$ \\
size_v & $-318.914^{*}$ \\
& $(-1.661)$ \\
level_v & $439.090^{* * *}$ \\
& $(3.391)$ \\
tobinq_v & $-185.826^{* * *}$ \\
& $(-3.839)$ \\
cash_v & $-161.203 * * *$ \\
& $(-3.927)$ \\
roa_v & $0.673 * *$ \\
& $(1.973)$ \\
H10_v & 19.801 \\
& $(1.129)$ \\
age_v & $426.779 * * *$ \\
& $(3.288)$ \\
Constant & -30.689 \\
Industry & $(-1.202)$ \\
Observations & Yes \\
Novels, respectively & 2,444 \\
\hline indicate statistical significance at the $10 \%, 5 \%$ and \\
\end{tabular}

\section{ACKNOWLEDGMENT}

This research was funded by the National Natural Science Foundation of China, grant number 71571007, 71850007.

\section{REFERENCES}

1. Cull R, Xu L C, Yang X, et al. Market facilitation by local government and firm efficiency: Evidence from China[J]. Journal of Corporate Finance, 2017, 42: 460-480.

2. Lv M, Bai M. Political uncertainty and corporate debt financing: empirical evidence from China[J]. Applied Economics, 2019, 51(13): 1433-1449. 
3. Bloom, N., Bond, S., Van Reenen, J. Uncertainty and investment dynamics[J]. The Review of Economic Studies, 2007, 74(2), 391-415.

4. Francis B B , Hasan I, Zhu Y . Political uncertainty and bank loan contracting $[\mathrm{J}]$. Journal of Empirical Finance, 2014, 29:281-286.

5. Julio, B., Yook, Y. Political turnover and corporate investment cycles[J]. Journal of Finance, 2012, 67 (1), 45-83.

6. Yonce A. US Corporate Investment Over the Political Cycle [J]. The Quarterly Journal of Finance, 2015, 5(01): 1550015.

7. An H, Chen Y, Luo D, et al. Political uncertainty and corporate investment: Evidence from China[J]. Journal of Corporate Finance, 2016, 36: 174-189. 